University of Nebraska - Lincoln

DigitalCommons@University of Nebraska - Lincoln

Determination of dimethylselenide and dimethyldiselenide by gas chromatography-photoionization detection

\author{
William J. Hunter \\ United States Department of Agriculture \\ L. David Kuykendall \\ United States Department of Agriculture
}

Follow this and additional works at: https://digitalcommons.unl.edu/usdaarsfacpub

Part of the Agricultural Science Commons

Hunter, William J. and Kuykendall, L. David, "Determination of dimethylselenide and dimethyldiselenide by gas chromatography-photoionization detection" (2004). Publications from USDA-ARS / UNL Faculty. 357. https://digitalcommons.unl.edu/usdaarsfacpub/357

This Article is brought to you for free and open access by the U.S. Department of Agriculture: Agricultural Research Service, Lincoln, Nebraska at DigitalCommons@University of Nebraska - Lincoln. It has been accepted for inclusion in Publications from USDA-ARS / UNL Faculty by an authorized administrator of DigitalCommons@University of Nebraska - Lincoln. 


\title{
Determination of dimethylselenide and dimethyldiselenide by gas chromatography-photoionization detection
}

\author{
William J. Hunter $^{\mathrm{a}, *}$, L. David Kuykendall ${ }^{\mathrm{b}}$ \\ ${ }^{a}$ US Department of Agriculture, Agricultural Research Service, Suite 100, 2150D Centre Avenue, Fort Collins, CO 80526-8119, USA \\ ${ }^{\mathrm{b}}$ US Department of Agriculture, Agricultural Research Service, BARC-W, Building 004, 10300 Baltimore Avenue, Beltsville, MD 20705, USA
}

Received 9 December 2003; received in revised form 4 March 2004; accepted 4 March 2004

Available online 12 April 2004

\begin{abstract}
A simple method for the determination of volatile selenium compounds employing a gas chromatograph equipped with a photoionization detector is described. The method involves the direct injection of dimethylselenide (DMS) or dimethyldiselenide (DMDS) into the gas chromatograph; no derivatization of the sample was required. The photoionization detector was capable of detecting $60 \mathrm{pg}(0.55 \mathrm{pmol})$ of DMS and $150 \mathrm{pg}(0.80 \mathrm{pmol})$ DMDS. Sensitivity was 10-50 times greater with DMS and 4-20 times greater with DMDS when the photoionization detector was employed than when the flame ionization detector was employed.
\end{abstract}

(C) 2004 Elsevier B.V. All rights reserved.

Keywords: Organoselenium compounds; Selenium; Selenides

\section{Introduction}

Selenium is a common environmental element whose presence in soils and groundwaters may be due to either natural or anthropogenic activities. In small amounts, inorganic selenium is an essential element; however, in large amounts, selenium toxicity can cause fatigue, irritability, and damage to the nervous system [1]. Many plants and microorganisms can transform inorganic selenium species into volatile organic species. This biological activity is important in the global cycling of selenium and is an important step in reducing the toxicity of inorganic selenium in soils. Volatile organic species escape from the soil and are far less toxic than are inorganic selenium species [2]. Dimethylselenide is the most common volatile organic selenium species produced by microorganisms $[3,4]$.

There have been a number of reviews on the analysis of selenium and selenium-containing compounds and a number of analytical procedures are available [5-10]. Atomic absorption spectrometry (AAS) is perhaps the most commonly used method for total selenium analysis [10] with hydride

\footnotetext{
* Corresponding author. Tel.: +1-970-492-7208; fax: +1-970-492-7213.

E-mail address: william.hunter@ars.usda.gov (W.J. Hunter).
}

generation AAS being the most sensitive of the AAS procedures. For dimethylselenide (DMS) and dimethyldiselenide (DMDS), detection limits of 5-25 pg have been reported [5]. For the AAS analysis of gaseous selenides, the vapors must first be trapped and then oxidized to selenite for analysis.

Gas chromatography (GC) has been used to identify and determine the amount of volatile organic selenium species in samples. Flame ionization detection (FID) has been employed as a method for the detection of DMS and DMDS. FID analysis is simple, requiring no sample derivatization or other sample preparation, and is cost effective, in that FID detectors are inexpensive. In addition, FID systems are probably the most common detectors available on gas chromatographs. However, FID is not as sensitive as many alternative approaches. Also, flame ionization detectors, because they detect hydrocarbons and because there are so many different hydrocarbon compounds, have poor selectivity. Electron-capture detection (ECD) has also been employed to measure organoselenium compounds. This approach offers good selectivity and detection limits in the picogram range but requires that the selenium species be derivatized to a form that can be detected by ECD [11-13]. Mass spectrometry and hydride generation AAS can be coupled to GCs and used to detect DMS and DMDS [5]. Mass spectrometry offers very high assurance of sample identity 
and detection limits that are in the picogram range for many organoselenium compounds $[13,14]$ though the cost of mass spectrometry can be a problem for some laboratories.

Colorimetric approaches are also available but are tedious and offer very low sample throughput. These approaches involve trapping of the volatile selenium species and conversion to selenite for colorimetric measurement [10]. With any procedure involving the chemical alteration of the volatile selenium species, be it derivatization for ECD measurement or conversion to selenite for chemical or AAS measurement, losses caused by incomplete transformation during the process can be a problem.

The objective of this study was to evaluate the use of photoionization detection (PID) as a simple procedure for the direct measurement of DMS and DMDS and to compare this procedure with the direct measurement of these compounds with FID.

\section{Experimental}

\subsection{Instrumentation}

Gas chromatography was carried out using a HewlettPackard 5790 instrument equipped with a Hewlett-Packard FID system and with a HNU Systems (Newton, MA, USA) model PI 52-02A photoionization detector. Liquid injections were $1 \mu \mathrm{l}$ and headspace injections were $500 \mu \mathrm{l}$ in volume. Injection was into a split-splitless injector operated in the splitless mode. Port temperature was $235^{\circ} \mathrm{C}$. Peak separation was achieved on a GS-Q $30 \mathrm{~m} \times 0.540 \mathrm{~mm}$ column supplied by J\&W Scientific (Folsom, CA, USA). The carrier gas was helium at $37 \mathrm{ml} \mathrm{min}^{-1}$. Oven temperature varied from study to study. The FID system was operated at $235^{\circ} \mathrm{C}$ with hydrogen supplied at $30 \mathrm{ml} \mathrm{min}^{-1}$ and air supplied at $240 \mathrm{ml} \mathrm{min}^{-1}$. The PID system was operated with a $10.2 \mathrm{eV}$ bulb at $235^{\circ} \mathrm{C}$. Peak area was estimated using a Shimadzu Class VP electronic integrator.

\subsection{Materials}

DMS and DMDS were obtained from Sigma-Aldrich (Milwaukee, WI, USA). Stock solutions containing $1000 \mathrm{ng}_{\mu l^{-1}}$ were prepared by diluting $7.1 \mu \mathrm{l}$ of DMS or
5.0 $\mu \mathrm{l}$ DMDS into $10.0 \mathrm{ml}$ methanol. Standard solutions in methanol containing $100,10,1$ and $0.1{\mathrm{ng} \mu \mathrm{l}^{-1}}$ were prepared by serial dilution of the stock solution.

\subsection{Soil columns}

Columns were $2.6 \mathrm{~cm} \times 30 \mathrm{~cm}$ glass tubes filled with a support matrix of 30 grit $(0.35 \mathrm{~mm}$ sieve size $)$ washed quartz sand coated with $2.5 \mathrm{~g}$ of soybean oil and packed to a bulk density of $1.49 \mathrm{~g} \mathrm{ml}^{-1}$. Reconstituted water [15] supplemented with $10 \mathrm{mgl}^{-1}$ selenite-Se was pumped upwardly through the columns at $1.8 \mathrm{ml} \mathrm{h}^{-1}$ throughout the study. Columns were inoculated with a soil wash [16] and incubated in the dark at $15^{\circ} \mathrm{C}$ for 5 weeks. Gases forming in the columns were collected in an all glass and stainless steel effluent line gas trap equipped with a Teflon-lined rubber septum. A syringe equipped with a valve was used to transfer $0.5 \mathrm{ml}$ of "effluent gas" to the GC inlet.

\subsection{Statistical comparisons}

Statistical comparisons and linear regression analysis were made using the Instat computer program (GraphPad Software).

\section{Results and discussion}

\subsection{PID analysis}

The GC system was capable of resolving and detecting picogram amounts of DMS when the PID was used. This was demonstrated by injecting a sample containing $100 \mathrm{pg}$ DMS into a $140{ }^{\circ} \mathrm{C}$ isothermal GC. Under the conditions used for this study, the limit of detection (LOD), using the three times noise criterion, was about $60 \mathrm{pg}(0.55 \mathrm{pmol})$ for DMS. The LOD was higher with the DMDS analysis. No peak was detected when a $100 \mathrm{pg}$ sample of DMDS was injected into a $220^{\circ} \mathrm{C}$ isothermal $\mathrm{GC}$, but a peak of about 10 times noise was detected when a $500 \mathrm{pg}$ sample of DMDS was injected. Thus, the minimum amount detectable would be about $150 \mathrm{pg}(0.80 \mathrm{pmol})$. Detector response was linear over the range evaluated with both compounds (Table 1).

Table 1

Figures of merit

\begin{tabular}{|c|c|c|c|c|c|c|c|c|c|}
\hline \multirow[t]{2}{*}{ Detector } & \multirow[t]{2}{*}{ Compound } & \multicolumn{5}{|c|}{ Reproducibility with DMS or DMDS (R.S.D., $\% ; n=3$ ) } & \multicolumn{3}{|c|}{ Calibration $(y=k x+d)^{\mathrm{a}}$} \\
\hline & & $0.1 \mathrm{ng}$ & $1.0 \mathrm{ng}$ & $10 \mathrm{ng}$ & $100 \mathrm{ng}$ & $1000 \mathrm{ng}$ & $k$ & $d$ & $r^{2}$ \\
\hline \multirow[t]{2}{*}{ FID } & DMS & $\mathrm{ND}^{\mathrm{b}}$ & ND & 20.1 & 5.9 & 1.7 & 530 & 282 & 0.9997 \\
\hline & DMDS & ND & ND & 19.4 & 3.7 & 3.0 & 364 & 2 & 0.9991 \\
\hline \multirow[t]{2}{*}{ PID } & DMS & 6.8 & 0.5 & 1.4 & 2.8 & 4.3 & 461 & 127 & 0.9984 \\
\hline & DMDS & ND & 10.6 & 6.9 & 4.2 & 5.6 & -1479 & 746 & 0.9972 \\
\hline
\end{tabular}

\footnotetext{
a $y=$ peak area (counts $\left.\mathrm{s}^{-1}\right) ; x=$ concentation of DMS or DMDS in nanograms.
}

b Not detected. 


\subsection{FID analysis}

When the GC system was operated in the isothermal mode at $140^{\circ} \mathrm{C}$ and the FID employed as the detector the LOD was between 1 and $5 \mathrm{ng}$ of DMS. This was in part due to the large peak formed by the methanol solvent. DMS appeared as a tangent peak on the tail of the methanol peak and the methanol tail interfered with the integration of the DMS peak. This was less of a problem with the PID system as methanol does not produce a large peak with this detector. Reducing the temperature of the oven to $110^{\circ} \mathrm{C}$ isothermal reduced the interference caused by the methanol tail but did not lower the detection limit. With DMDS, the LOD was between 10 and $100 \mathrm{ng}$ when the GC was operated in the isothermal mode at $220^{\circ} \mathrm{C}$ (data not presented), and, as was the case with DMS, the tail of the methanol solvent peak interfered with the integration of the peak. Reducing the temperature of the oven to $180^{\circ} \mathrm{C}$ isothermal, lowered the detection limit to about $5 \mathrm{ng}$. Detector response was linear over the range evaluated with both DMS and DMDS (Table 1).

\subsection{Soil column gas analysis}

The analysis of DMS and DMDS standards in gas samples worked well and achieved detection limits that were similar to those observed with liquid samples containing DMS and DMDS (data not presented). Based on these results with gas samples, headspace analysis of samples collected weekly was used to monitor the formation of DMS and DMDS in the gaseous effluent of three soil columns over a period of 6 weeks. In the first 3 weeks of operation, no DMS was detected in the effluents from these columns but in week $4,3 \pm 1 \mathrm{ml}$ of gas containing $0.68 \mathrm{ng} \mathrm{ml}^{-1}$ DMS $(0.338 \pm$

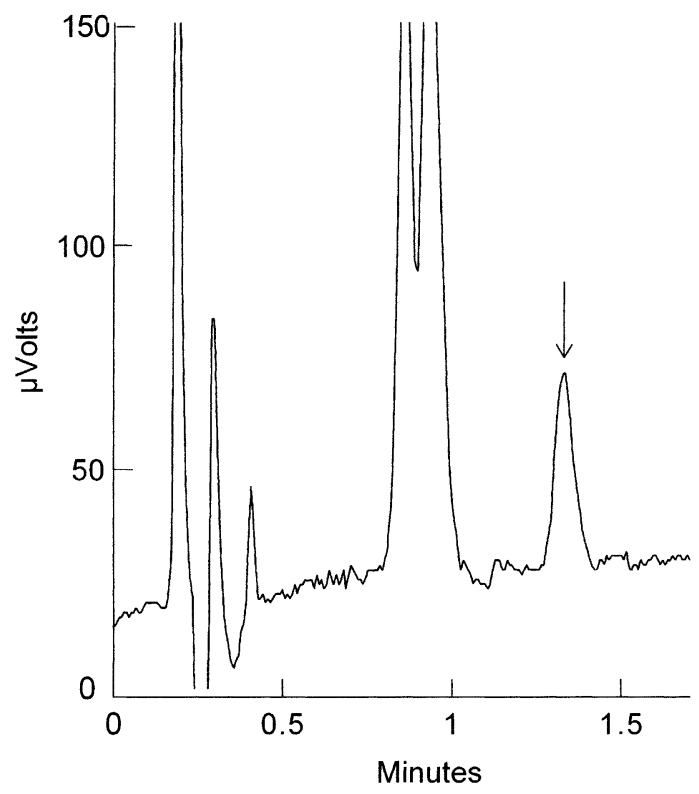

Fig. 1. DMS, $470 \mathrm{pg}$ in a $0.5 \mathrm{ml}$ headspace sample, collected in a gas trap placed in the effluent line from a 4-week-old soil column fed selenite in the influent buffer.
$0.092 \mathrm{ng}$ per $0.5 \mathrm{ml}$ injection) was detected (Fig. 1). In week $5,3 \pm 0.4 \mathrm{ml}$ of gas containing $0.99 \mathrm{ng} \mathrm{ml}^{-1}$ DMS $(0.494 \pm$ $0.124 \mathrm{ng}$ per $0.5 \mathrm{ml}$ injection) was detected in the "effluent gas" from the columns. No DMDS was detected.

\section{Conclusions}

The PID was found to provide a simple and sensitive method for the determination of DMS and DMDS in both liquid and headspace samples. With DMS, the PID was 10-50 times more sensitive than FID; with DMDS, PID was 4-20 times more sensitive than FID. Detection limits when the PID was employed were about $60 \mathrm{pg}(0.55 \mathrm{pmol})$ with DMS and $150 \mathrm{pg}(0.80 \mathrm{pmol})$ with DMDS. Similar detection limits were observed when gas samples were injected and PID proved to be a useful detection method for analyzing DMS vapors evolving from soil columns.

\section{Acknowledgements}

We thank Robin Montenieri and Ryan Vaughn for their expert technical assistance. Mention of manufacturer or product brand name is made for the reader's convenience and does not reflect endorsement by the US government. This paper was the work of US government employees engaged in their official duties and is therefore exempt from copyright.

\section{References}

[1] http://www.epa.gov/ogwdw000/dwh/t-ioc/selenium.html, US Environmental Protection Agency, 2002.

[2] C.G. Wilber, Clin. Toxicol. 17 (1990) 171.

[3] R. Zieve, P.J. Ansell, T.W.K. Young, Trans. Br. Mycol. Soc. 84 (1985) 177.

[4] W.T. Frankenberger, U. Karlson, in: W.T. Frankenberger, S. Benson (Eds.), Selenium in the Environment, Marcel Dekker, New York, 1994, p. 369.

[5] X. Dauchy, M. Potin-Gautier, A. Astruc, M. Astruc, Fresenius J. Anal. Chem. 348 (1994) 792.

[6] P.M. Huang, R. Fujii, in: D.L. Sparks, A.L. Page, P.A. Helmke, R.H. Loeppert, P.N. Soltanpour, M.A. Tabatabai, Ct.T. Johnston, M.E. Summer, J.M. Bartels, J.M. Bigham (Eds.), Methods of Soil Analysis. Part 3. Chemical Methods, American Society of Agronomy and Soil Science Society of America, Madison, WI, 1996, p. 793.

[7] K. Pyrzyñska, Analyst 121 (1996) 77R.

[8] K. Pyrzyñska, Anal. Sci. 14 (1998) 479.

[9] K. Pyrzyñska, Talanta 55 (2001) 657.

[10] A.E. Greenberg, L.S. Clesceri, A.D. Eaton (Eds.), Standard Methods for the Examination of Water and Wastewater, American Public Health Association, American Water Works Association and Water Environmental Federation, Washington, DC, 1992. pp. 3-82.

[11] S. Dilli, I. Sutikno, J. Chromatogr. 300 (1984) 265.

[12] A. Elaseer, G. Nickless, J. Chromatogr. A 664 (1994) 77.

[13] J.L. Gomez-Ariza, J.A. Pozas, I. Giraldez, E. Morales, J. Chromatogr. A 823 (1998) 259.

[14] W. Goessler, D. Kuehnelt, C. Schlagenhaufen, K. Kalcher, M. Abegaz, K.J. Irgolic, J. Chromatogr. A 789 (1997) 233.

[15] W.J. Hunter, J. Contam. Hydrol. 53 (2001) 119.

[16] W.J. Hunter, Curr. Microbiol. 45 (2002) 287. 